\title{
How do Today's Modern Passenger Cars Brake?
}

\author{
Ján Ondruš $^{1 *}$, Pavol Kohút ${ }^{2}$, Rastislav Jurina ${ }^{2}$ and Klaus - Dieter Brösdorf ${ }^{3}$
}

${ }^{1}$ University of Zilina, Department of road and urban transport, Univerzitná 8251/1, 01026 Zilina, Slovak Republic; Email: jan.ondrus@fpedas.uniza.sk

${ }^{2}$ University of Zilina, Institute of Forensic Research and Education, Ulica 1. mája 32, 01001 Zilina, Slovak Republic; Email: pavol.kohut@usi.sk, rastislav.jurina@expertgroup.sk

${ }^{3}$ Westsächsische Hochschule Zwickau, Fakultät Kraftfahrzeugtechnik, Höhenweg 13, CH-9630 Wattwil SG, Germany; Email: Klaus-Dieter.Broesdorf@t-online.de

\section{*Corresponding Author: Ján Ondruš}

\begin{abstract}
The article deals with issues of vehicle braking from different points of view. We made repeated braking tests of modern vehicles during intensive braking on various asphalt surfaces with the goal to evaluate character of this random variable. We dedicated our attention also to the accuracy attainable using various measuring methods and equipment. Within measurement of braking deceleration we used low-end measuring device (mobile smartphone) and measuring devices most used in Slovakia (XL Meter TM Pro Gamma). The collected data were processed in the software XL Vision and evaluated by SW PC-Crash 10.9. Usable result from article is mainly measurement set of braking deceleration of current modern vehicles during intensive braking on various asphalt surfaces as well as evaluation of accuracy levels with respect to various used devices.
\end{abstract}

Keywords: Braking, deceleration, mobile smartphone, XL Meter ${ }^{\mathrm{TM}}$ Pro Gamma, passenger cars

\section{Introduction}

The braking deceleration value during intensive braking belongs to the important input data of the accident analysis. Only a small number of measurements made with the current modern vehicles on common roads is published in the relevant literature. In this article the authors present their measurements results (modern vehicles decelerations) and also compare the different deceleration measurement methods mainly considering minimal measurement costs $[1,2]$.

\section{The Set of Measured Vehicles}

The set of vehicles, with which the individual measurements were performed, and also particular vehicle parameters and tyres are stated in the Tab. 1. 
Table 1 Vehicles used and their parameters. Source: authors

\begin{tabular}{|c|c|c|c|c|c|}
\hline Vehicle & $\begin{array}{c}\text { Year of } \\
\text { production }\end{array}$ & $\begin{array}{c}\text { Spent } \\
\text { kilometers }\end{array}$ & Type & Producer & $\begin{array}{l}\text { Type, dimension, weight } \\
\text { index, speed index, tyre } \\
\text { profile depth }\end{array}$ \\
\hline $\begin{array}{l}\text { Škoda Octavia Ambition } \\
\text { Limousine } 2.0 \text { TDI, } 110 \mathrm{~kW}\end{array}$ & 2015 & 5990 & Summer & Continental & $\begin{array}{l}\text { ContiEcoContact, 205/55 } \\
\text { R16 V,91V, } 8 \mathrm{~mm}\end{array}$ \\
\hline $\begin{array}{l}\text { Škoda Rapid } 1.2 \text { TSI } 66 \\
\text { kW, Spaceback Ambition }\end{array}$ & 2015 & 3525 & Summer & DUNLOP & $\begin{array}{l}\text { SPORT 01, 185/60 R15, } \\
84 \mathrm{H}, 8 \mathrm{~mm}\end{array}$ \\
\hline $\begin{array}{l}\text { Škoda Superb Combi } 2.0 \\
\text { TDI DSG } 140 \text { kW, L\&K }\end{array}$ & 2016 & 2176 & Summer & Pirelli & $\begin{array}{l}\text { Cinturato P7, 235/40 R19, } \\
96 \mathrm{~W}, 8 \mathrm{~mm}\end{array}$ \\
\hline $\begin{array}{l}\text { Škoda Yeti } 1.4 \text { TSI } \\
\text { Ambition }\end{array}$ & 2015 & 4200 & Summer & Continental & $\begin{array}{l}\text { ContiPremiumContact } 2 \text {, } \\
215 / 60 \mathrm{R} 16,95 \mathrm{H}, 8 \mathrm{~mm}\end{array}$ \\
\hline $\begin{array}{l}\text { VW e-Golf Comfortline } 85 \\
\mathrm{~kW}\end{array}$ & 2015 & 15267 & Summer & Continental & $\begin{array}{l}\text { Conti.eContact, } 205 / 55 \mathrm{R} \\
16,910,8 \mathrm{~mm}\end{array}$ \\
\hline $\begin{array}{l}\text { Opel Zafira Cosmo } 2.0 \\
\text { CDTi }\end{array}$ & 2016 & 18027 & Summer & Continental & $\begin{array}{l}\text { ContiSportContact } 3,225 / 50 \\
\text { R17, } 8 \mathrm{~mm}\end{array}$ \\
\hline $\begin{array}{l}\text { VW-Golf GTD Variant } 135 \\
\mathrm{~kW}\end{array}$ & 2015 & 14638 & Summer & Bridgestone & $\begin{array}{l}\text { Potenza, 225/40 R18, 92Y, } \\
8 \mathrm{~mm}\end{array}$ \\
\hline
\end{tabular}

The individual intensive braking measurements were repeatedly performed on the different road surfaces, the driver was trying to reach an initial speed similar to the one from which the vehicle was fully braking, specifically $50 \mathrm{~km} / \mathrm{h}, 70 \mathrm{~km} / \mathrm{h}$ and $90 \mathrm{~km} / \mathrm{h}$. The individual measurements (the process of accelerating period and the intensive braking) were registered by the decelerometer XL Meter ${ }^{\mathrm{TM}}$ Pro Gamma (Inventure Automotive Electronics Research \& Development, Inc.).

For the comparison of the mean braking deceleration value evaluated from the record of the decelerometer XL Meter ${ }^{\mathrm{TM}}$ Pro Gamma and from the record of the mobile phone (Samsung Galaxy S5 mini) performed with the app Accelerometer Analyzer, the vehicles Opel Zafira and VW-Golf GTD and the measurement section no. 1 were used [3-5].

\section{Measurement Sections}

The individual measurements were performed on more measurement sections. The section, in the following text referred to as "the first section", or "the section no. 1", consisted of the direct section of the road without superelevations, with an asphalt surface not entirely new, but with no visible defects, which is in a long-term operation. The section, in the following text referred to as "the second section", or "the section no. 2", consisted of a moderately curved road section (descending in the part where the driveaway was performed) with an entirely new - not yet put into operation asphalt surface. Both section 1 and 2, as well as the detail of road surfaces, are shown at the Fig. 1 and 2 . 

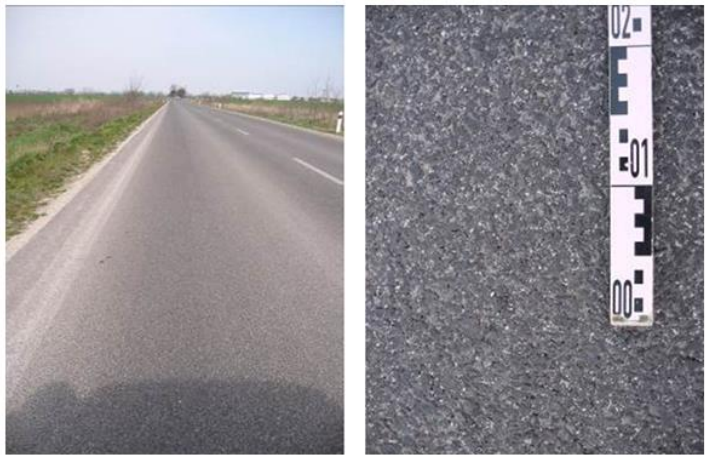

Fig. 1 Measurement section no. 1
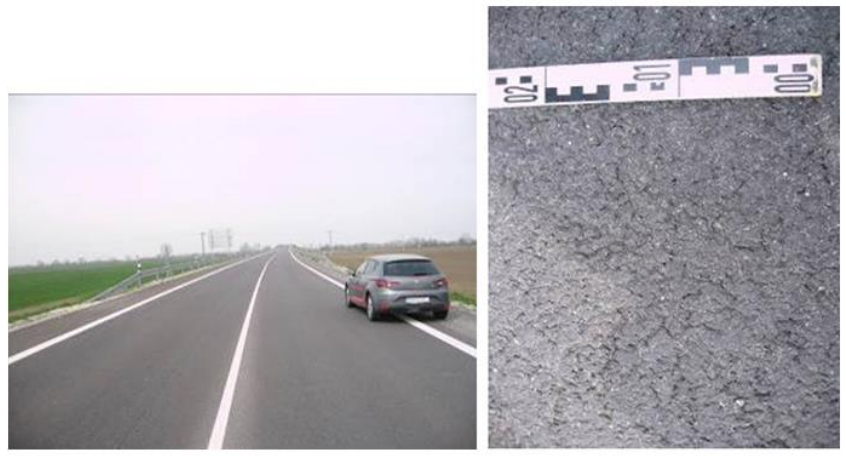

Fig. 2 Measurement section no. 2

\section{Measurement Methodologies and Measured Data Evaluation}

All of the measurements were performed on the dry road surface by the decelerometer XL Meter ${ }^{\mathrm{TM}}$ Pro Gamma, placed on the windshield of the vehicle. The record of a particular measurement from the vehicle VW e-Golf from the starting point to stopping of the vehicle after the full braking is shown at the Fig. 3.

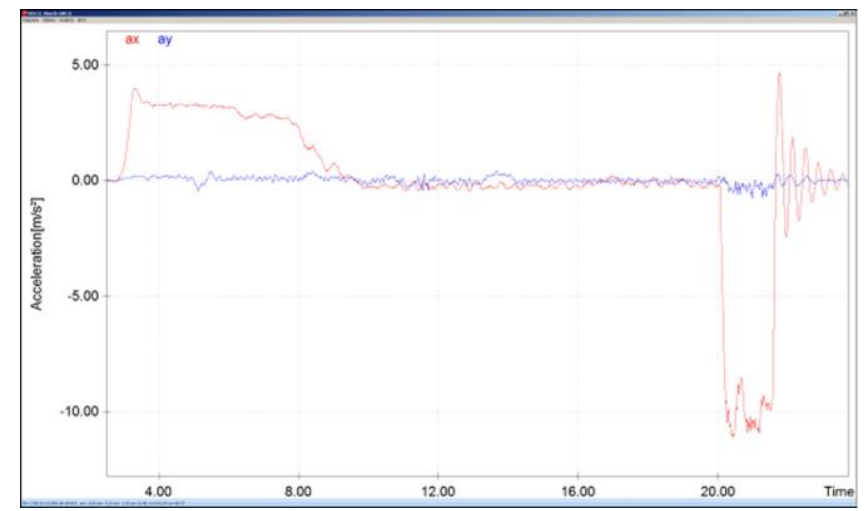

Fig. 3 The process of acceleration and deceleration during the whole measurement. Source: [5]

The detail of the recorded process of the vehicles' deceleration during the intensive braking of the vehicle VW e-Golf is shown at the Fig. 4.

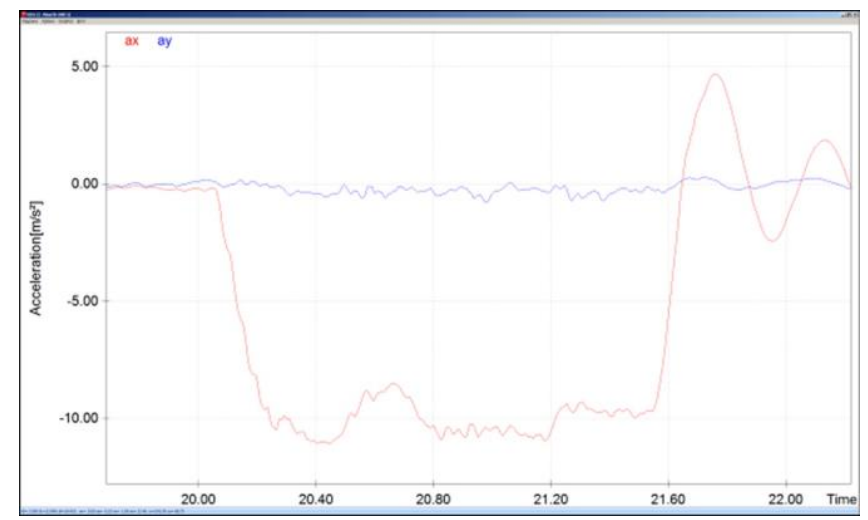

Fig. 4 The process of acceleration and deceleration during the whole measurement. Source: [5] 
The following procedure was used for the calculation of the mean braking deceleration value during the intensive braking: Using the backward integration of the deceleration process from the point of stopping of the vehicle after the intensive braking to the point of full braking deceleration we calculated the vehicle speed at the starting moment of the full braking deceleration [6,7]. Then using the backwards integration (of the calculated process of the vehicle speed) from the moment of vehicle stopping to the moment of the full braking deceleration we calculated the distance which the vehicle passed from the moment of full braking to the moment of stopping of the vehicle. By using the above described discreet values, the mean value of the vehicle deceleration during the intensive braking was calculated, using the following formula $[3,4,8]$ :

$$
a=\frac{v^{2}}{2 s}, \quad\left[\mathrm{~m} \cdot \mathrm{s}^{-2}\right]
$$

where: $v$ - vehicles' speed at the moment of the full braking deceleration $[\mathrm{m} / \mathrm{s}], s$ - the distance which the vehicle passed from the moment of the full braking deceleration to the vehicles' stopping $[\mathrm{m}]$.

During the braking process the vehicle, as well as the measuring device, is diving-in. Considering this, it is necessary to correct the mean braking deceleration value calculated as stated above. To make the correction it is necessary to know the vehicle diving-in angle $(\alpha)$. The diving-in angle was set using the video made perpendicularly to the vehicle direction during both standard driving and intensive braking. Using these two videos the vehicle diving-in value was specified. Consequently it was possible to calculate the real value of the mean braking deceleration of the vehicle during the intensive braking, using the following formula [1]:

$$
a_{s}=\frac{a_{m}}{\cos \alpha}-g \cdot \operatorname{tg} \alpha, \quad\left[\mathrm{m} . \mathrm{s}^{-2}\right]
$$

where: $a_{m}$ - mean braking deceleration value calculated by the above stated method $\left[\mathrm{m} \cdot \mathrm{s}^{-2}\right], \alpha-$ the vehicle body dive-in angle during the intensive braking $\left[{ }^{\circ}\right], a_{S}$ - the mean braking deceleration value corrected by the vehicle body dive-in angle $\left[\mathrm{m} . \mathrm{s}^{-2}\right]$.

\section{Measured and Evaluated Values}

Table 2 shows the measured and evaluated data of the individual vehicles on the dry road surface of the first measured section. The column „Front seat passenger“ states whether there was one or two persons in the vehicle. The value $\mathbf{V}$ indicates the vehicle speed at the moment of full braking deceleration for the relevant measurement. The value $\mathbf{s}$ indicates the distance which the vehicle 
passed from the moment of full braking deceleration till the vehicle stopping, during the relevant measurement. The value $\mathbf{a}_{\mathbf{m}}$ indicates the mean braking deceleration value calculated with the above mentioned method during the relevant measurement (less the vehicle body dive-in angle correction) and the value as indicates the mean braking deceleration value corrected by the vehicle body dive-in angle during the relevant measurement $[9,10]$.

Table 2 Measured and evaluated data for the section no. 1. Source: authors

\begin{tabular}{|c|c|c|c|c|c|c|c|}
\hline Vehicle & $\begin{array}{c}\text { Temperature } \\
{\left[{ }^{\circ} \mathrm{C}\right]} \\
\end{array}$ & $\begin{array}{l}\text { Front seat } \\
\text { passenger }\end{array}$ & $\begin{array}{c}\mathrm{V} \\
{[\mathrm{km} / \mathrm{h}]}\end{array}$ & $\begin{array}{c}\mathbf{s} \\
{[\mathbf{m}]}\end{array}$ & $\begin{array}{c}\mathbf{a}_{\mathbf{m}} \\
{\left[\mathbf{m} / \mathbf{s}^{2}\right]}\end{array}$ & $\begin{array}{c}\text { Dive-in } \\
\alpha\left[^{\circ}\right] \\
\end{array}$ & $\begin{array}{c}\mathbf{a}_{\mathrm{s}} \\
{\left[\mathrm{m} / \mathbf{s}^{2}\right]}\end{array}$ \\
\hline Octavia & 20 & no & 52.68 & 10.05 & 10.65 & 1.8 & 10.35 \\
\hline Octavia & 20 & no & 68.42 & 17.21 & 10.49 & 1.8 & 10.19 \\
\hline Octavia & 20 & no & 87.49 & 28.65 & 10.31 & 1.8 & 10.00 \\
\hline Octavia & 20 & yes & 48.92 & 9.06 & 10.19 & 1.8 & 9.89 \\
\hline Octavia & 20 & yes & 65.75 & 15.79 & 10.56 & 1.8 & 10.26 \\
\hline Octavia & 20 & yes & 93.6 & 32.48 & 10.41 & 1.8 & 10.10 \\
\hline Rapid & 20 & no & 46.7 & 7.93 & 10.61 & 1.8 & 10.31 \\
\hline Rapid & 20 & no & 64.63 & 15.01 & 10.74 & 1.8 & 10.43 \\
\hline Rapid & 20 & no & 83.21 & 25.2 & 10.60 & 1.8 & 10.30 \\
\hline Rapid & 20 & no & 48.95 & 8.57 & 10.79 & 1.8 & 10.48 \\
\hline Rapid & 20 & no & 67.98 & 16.78 & 10.63 & 1.8 & 10.32 \\
\hline Rapid & 20 & no & 83.66 & 25.48 & 10.60 & 1.8 & 10.29 \\
\hline Superb & 20 & no & 46.45 & 7.88 & 10.56 & 0.7 & 10.44 \\
\hline Superb & 20 & no & 72.56 & 19.62 & 10.35 & 0.7 & 10.23 \\
\hline Superb & 20 & no & 89.54 & 28.85 & 10.72 & 0.7 & 10.60 \\
\hline e-Golf & 31.5 & no & 49.85 & 9.48 & 10.11 & 1.6 & 9.84 \\
\hline e-Golf & 31.5 & no & 66.69 & 16.8 & 10.21 & 1.6 & 9.94 \\
\hline e-Golf & 31.5 & no & 86.61 & 28.01 & 10.33 & 1.6 & 10.06 \\
\hline e-Golf & 31.5 & no & 48.36 & 8.52 & 10.59 & 1.6 & 10.32 \\
\hline e-Golf & 31.5 & no & 66.3 & 16.52 & 10.27 & 1.6 & 10.00 \\
\hline e-Golf & 31.5 & no & 88.38 & 29.17 & 10.33 & 1.6 & 10.06 \\
\hline Yeti & 31.5 & no & 46.81 & 8.47 & 9.98 & 1.7 & 9.69 \\
\hline Yeti & 31.5 & no & 63.77 & 15.29 & 10.26 & 1.7 & 9.97 \\
\hline Yeti & 31.5 & no & 87.03 & 28.43 & 10.28 & 1.7 & 9.99 \\
\hline Golf GTD & 31.5 & yes & 47.74 & 8.1 & 10.86 & 1.5 & 10.60 \\
\hline Golf GTD & 31.5 & yes & 65.83 & 15.34 & 10.90 & 1.5 & 10.65 \\
\hline Golf GTD & 31.5 & yes & 83.65 & 24.33 & 11.10 & 1.5 & 10.84 \\
\hline Golf GTD & 30 & yes & 49.03 & 9.01 & 10.29 & 1,5 & 10.04 \\
\hline Golf GTD & 30 & yes & 67.92 & 16.56 & 10.75 & 1,5 & 10.49 \\
\hline Golf GTD & 30 & yes & 84.33 & 24.86 & 11.04 & 1.5 & 10.78 \\
\hline Zafira & 30 & yes & 51 & 10.69 & 9.39 & 0.9 & 9.23 \\
\hline Zafira & 30 & yes & 72.1 & 19.91 & 10.07 & 0.9 & 9.92 \\
\hline Zafira & 30 & yes & 90.53 & 31.57 & 10.02 & 0.9 & 9.86 \\
\hline
\end{tabular}

By processing the data for the section no. 1, the following frequency graph was created (Fig. 5). 


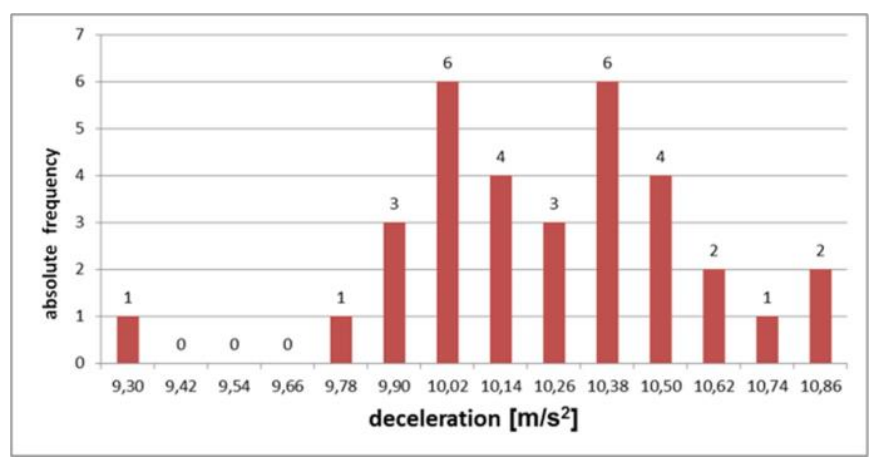

Fig. 5 Frequency graph for the tab. 2. Source: authors

Table 3 shows the measured and evaluated data for the individual measurements on the dry road surface of the second measurement section.

Table 3 Measured and evaluated data for the section no. 2. Source: authors

\begin{tabular}{lccccccc}
\hline \multicolumn{1}{c}{ Vehicle } & $\begin{array}{c}\text { Temperature } \\
{\left[{ }^{\circ} \mathbf{C}\right]}\end{array}$ & $\begin{array}{c}\text { Front seat } \\
\text { passenger }\end{array}$ & $\begin{array}{c}\mathbf{V} \\
{[\mathbf{k m} / \mathbf{h}]}\end{array}$ & $\begin{array}{c}\mathbf{s} \\
{[\mathbf{m}]}\end{array}$ & $\begin{array}{c}\left.\mathbf{a}_{\mathbf{m}}{ }^{2} \mathbf{m} / \mathbf{s}^{2}\right] \\
\text { Dive-in } \\
\boldsymbol{\alpha}\left[{ }^{\circ} \mathbf{l}\right.\end{array}$ & $\begin{array}{c}\mathbf{a}_{\mathbf{s}} \\
{\left[\mathbf{m} / \mathbf{s}^{2}\right]}\end{array}$ \\
\hline Rapid & 20 & no & 51.1 & 9.84 & 10.24 & 1.8 & 9.93 \\
\hline Rapid & 20 & no & 65.26 & 16.06 & 10.23 & 1.8 & 9.93 \\
\hline Rapid & 20 & no & 86.97 & 28.53 & 10.23 & 1.8 & 9.93 \\
\hline Rapid & 20 & yes & 51.81 & 10.09 & 10.26 & 1.8 & 9.96 \\
\hline Rapid & 20 & yes & 67.74 & 17.33 & 10.22 & 1.8 & 9.91 \\
\hline Rapid & 20 & yes & 87.49 & 28.6 & 10.33 & 1.8 & 10.02 \\
\hline Octavia & 20 & no & 54.71 & 11.38 & 10.15 & 1.8 & 9.84 \\
\hline Octavia & 20 & no & 70.68 & 19.21 & 10.03 & 1.8 & 9.73 \\
\hline Octavia & 20 & no & 90.59 & 31.95 & 9.91 & 1.8 & 9.61 \\
\hline Octavia & 20 & no & 49.37 & 9.53 & 9.87 & 1.8 & 9.56 \\
\hline Octavia & 20 & no & 69.23 & 18.41 & 10.04 & 1.8 & 9.74 \\
\hline Octavia & 20 & no & 87.9 & 29.72 & 10.03 & 1.8 & 9.73 \\
\hline Superb & 20 & no & 49.32 & 9.3 & 10.09 & 0.7 & 9.97 \\
\hline Superb & 20 & no & 70.25 & 18.72 & 10.17 & 0.7 & 10.05 \\
\hline Superb & 20 & no & 90.79 & 30.68 & 10.37 & 0.7 & 10.25 \\
\hline Superb & 20 & no & 49.08 & 9.41 & 9.88 & 0.7 & 9.76 \\
\hline Superb & 20 & no & 64.99 & 15.91 & 10.24 & 0.7 & 10.12 \\
\hline Superb & 20 & no & 90.67 & 31.02 & 10.22 & 0.7 & 10.11 \\
\hline e-Golf & 31.5 & no & 45.36 & 8.05 & 9.86 & 1.6 & 9.59 \\
\hline e-Golf & 31.5 & no & 65.55 & 17.03 & 9.73 & 1.6 & 9.46 \\
\hline e-Golf & 31.5 & no & 84.17 & 28.31 & 9.65 & 1.6 & 9.38 \\
\hline e-Golf & 31.5 & no & 54 & 11.51 & 9.77 & 1.6 & 9.50 \\
\hline e-Golf & 31.5 & no & 68.87 & 19.17 & 9.55 & 1.6 & 9.28 \\
\hline e-Golf & 31.5 & no & 86.78 & 29.66 & 9.80 & 1.6 & 9.53 \\
\hline Yeti & 31.5 & no & 51.54 & 10.68 & 9.60 & 1.7 & 9.31 \\
\hline Yeti & 31.5 & no & 69.76 & 19.18 & 9.79 & 1.7 & 9.50 \\
\hline Yeti & 31.5 & no & 88.87 & 31.85 & 9.57 & 1.7 & 9.28 \\
\hline 31.5 & no & 47.91 & 9.17 & 9.66 & 1.7 & 9.37 \\
\hline & 31.5 & no & 66.55 & 17.64 & 9.69 & 1.7 & 9.40 \\
\hline & & no & 85.67 & 29.05 & 9.75 & 1.7 & 9.46 \\
\hline
\end{tabular}


By processing the data for the section no. 2, the following frequency graph was created (Fig. 6).

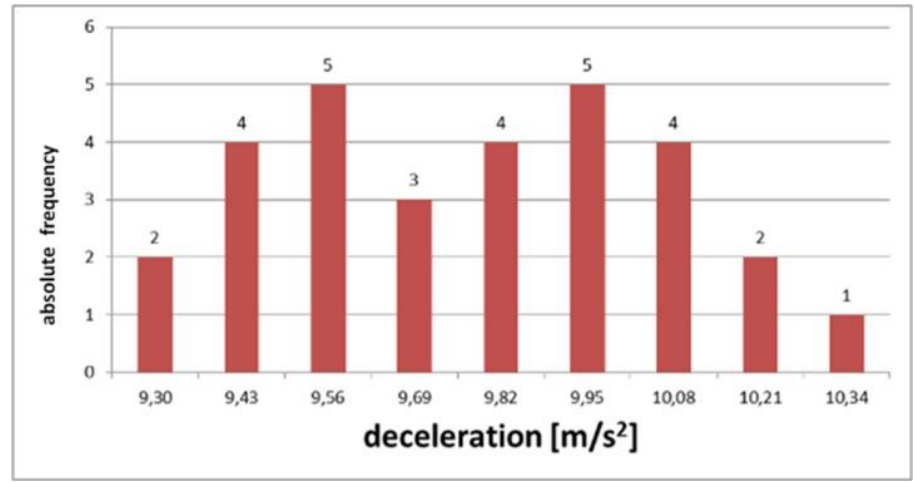

Fig. 6 Frequency graph for the tab. 3. Source: authors

Using the data from both tables (2 and 3) the following frequency graph was created (Fig. 7). It clearly shows the character of vehicle braking deceleration during the intensive braking.

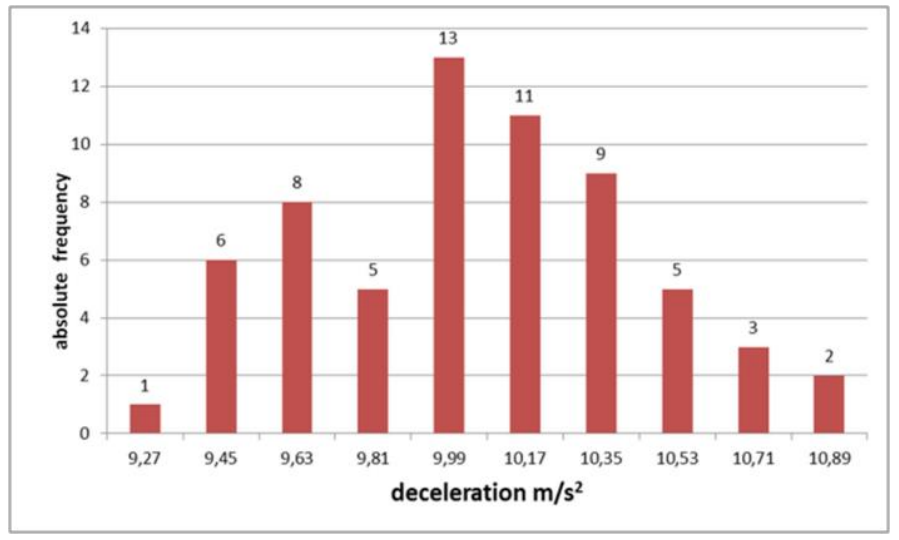

Fig. 7 Frequency graph for the tab. 2 and the tab. 3. Source: authors

Table 4 shows the comparison of the selected statistical parameters (arithmetic average, minimum, maximum, standard deviation) for the first and the second section on the dry road surface.

Table 4 Measured and evaluated data. Source: authors

\begin{tabular}{lccccc}
\hline Vehicle & Section & \multicolumn{2}{c}{$\begin{array}{c}\text { Measured } \\
\text { deceleration value }\end{array}$} & $\begin{array}{c}\text { Arithmetical } \\
\text { average of the } \\
\text { deceleration }\end{array}$ & $\begin{array}{c}\text { Standard } \\
\text { deviation of the } \\
\text { deceleration }\end{array}$ \\
\cline { 2 - 6 } Octavia & 1 & 9.89 & 10.35 & 10.13 & 0.17 \\
\hline Octavia & 2 & 9.56 & 9.84 & 9.7 & 0.1 \\
\hline Rapid & 1 & 10.29 & 10.48 & 10.36 & 0.08 \\
\hline Rapid & 2 & 9.91 & 10.02 & 9.95 & 0.04 \\
\hline Superb & 1 & 10.23 & 10.6 & 10.43 & 0.18 \\
\hline Superb & 2 & 9.76 & 10.25 & 10.04 & 0.17 \\
\hline e-Golf & 1 & 9.84 & 10.32 & 10.04 & 0.16 \\
\hline e-Golf & 2 & 9.28 & 9.59 & 9.46 & 0.11 \\
\hline Yeti & 1 & 9.69 & 9.99 & 9.89 & 0.17 \\
\hline Yeti & 2 & 9.28 & 9.50 & 9.39 & 0.09 \\
\hline & & & & & \\
\hline
\end{tabular}


Table 4 follows, that the statistical parameters in the first section are similar to the statistical parameters in the second section. Arithmetical average of the deceleration in the first section is for each individual vehicle higher than in the second section. This statement is valid also for the minimum and maximum. The standard deviation in the first section is always smaller than in the second section $[3,11]$.

\section{Accuracy Reached with the Use of the Smartphone}

The deceleration can also be measured with mobile phones. If a suitable measurement method is used, an acceptable accuracy is reached. Such mobile phone holder should be used, which enables the phone to be placed vertically, but has as little movable parts as possible, as these could either change the vertical position of the mobile phone during the measuring, or they could vibrate. To set the mobile phone into the vertical position an application Best Level was used, which shows in degrees the deviation of the mobile phone from the vertical axes $[12,13]$.

To compare the accuracy of the measurement performed by the mobile phone (Samsung Galaxy S5 mini) a series of measurements with the vehicles Opel Zafira and VW-Golf GTD were performed, where the vehicle deceleration was recorded by the decelerometer XL Meter ${ }^{\mathrm{TM}}$ Pro Gamma and also by mobile phone placed in the holders on the windshield (Fig. 8). The measurement was performed on the dry road on the section no. 1.

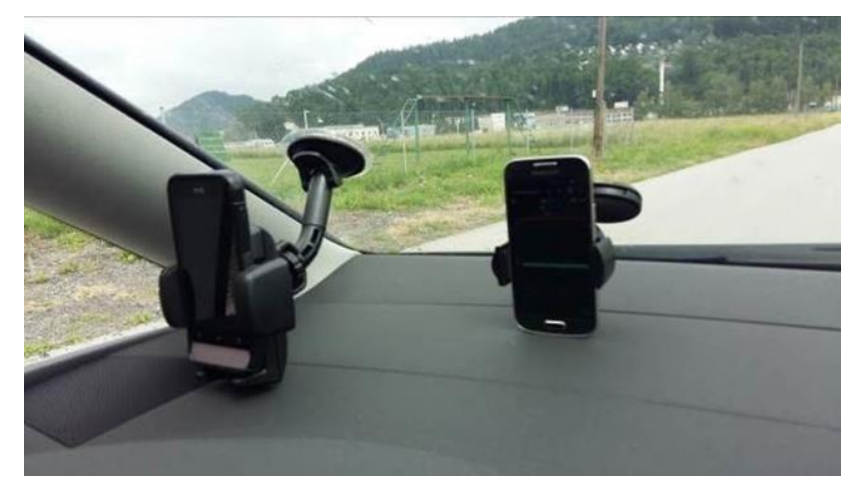

Fig. 8 Mobile phones holders. Source: authors

These measurements results comparison is shown in table 5. The value $\mathbf{V}$ indicates the vehicle speed at the moment of the full braking deceleration during the respective measurement. The value $\mathbf{s}$ indicates the distance which the vehicle passed from the moment of the full braking deceleration till the vehicle stopping during the respective measurement. The value $\mathbf{a}_{\mathbf{x}}$ indicates the mean braking deceleration value calculated by the above stated method during the respective measurement and using the XL-meter data. The value $\mathbf{a}_{\mathbf{p}}$ indicates the mean braking deceleration value calculated by 
the above stated method during the respective measurement and using the mobile phone data. To record the individual data in the mobile phone the application Accelerometer Analyzer was used.

Table 5 Measured and evaluated data from the XL Meter ${ }^{\mathrm{TM}}$ Pro Gamma and smartphone. Source: authors

\begin{tabular}{|c|c|c|c|c|c|}
\hline \multirow[t]{2}{*}{ Vehicle } & \multicolumn{3}{|c|}{$\begin{array}{c}\text { XL Meter }{ }^{\text {TM }} \text { Pro } \\
\text { Gamma }\end{array}$} & \multirow{2}{*}{$\begin{array}{c}\begin{array}{c}\mathbf{S 5} \\
\mathrm{mini}\end{array} \\
\begin{array}{c}\mathbf{a}_{\mathbf{P}} \\
{\left[\mathrm{m} / \mathbf{s}^{2}\right]}\end{array}\end{array}$} & \multirow{2}{*}{$\mathbf{a}_{\mathbf{x}}-\mathbf{a}_{\mathrm{p}}$} \\
\hline & $\begin{array}{c}\mathrm{V} \\
{[\mathrm{km} / \mathrm{h}]}\end{array}$ & $\begin{array}{c}\mathbf{s} \\
{[\mathbf{m}]}\end{array}$ & $\begin{array}{c}\mathbf{a}_{\mathbf{x}} \\
{\left[\mathbf{m} / \mathbf{s}^{2}\right]}\end{array}$ & & \\
\hline Golf GTD & 47.74 & 8.1 & 10.86 & 11.0 & -0.14 \\
\hline Golf GTD & 65.83 & 15.34 & 10.90 & 10.9 & 0.00 \\
\hline Golf GTD & 83.65 & 24.33 & 11.10 & 11.08 & 0.02 \\
\hline Golf GTD & 49.03 & 9.01 & 10.29 & 10.34 & -0.05 \\
\hline Golf GTD & 67.92 & 16.56 & 10.75 & 10.73 & 0.02 \\
\hline Golf GTD & 84.33 & 24.86 & 11.04 & 11.11 & -0.07 \\
\hline Golf GTD & 48.53 & 8.85 & 10.27 & 10.51 & -0.24 \\
\hline Zafira & 51 & 10.69 & 9.39 & 9.25 & 0.14 \\
\hline Zafira & 72.1 & 19.91 & 10.07 & 9.94 & 0.13 \\
\hline Zafira & 90.53 & 31.57 & 10.02 & 9.85 & 0.17 \\
\hline Zafira & 50.86 & 10.74 & 9.29 & 9.27 & 0.02 \\
\hline Zafira & 51,1 & 10.95 & 9.20 & 9.16 & 0.04 \\
\hline Zafira & 70.39 & 20.45 & 9.35 & 9.31 & 0.04 \\
\hline Zafira & 85.69 & 31.65 & 8.95 & 8.79 & 0.16 \\
\hline
\end{tabular}

The following figure 9 shows the comparison of the deceleration recorded by the mobile phone Samsung Galaxy S5 mini (green colour) and by the decelerometer XL Meter ${ }^{\mathrm{TM}}$ Pro Gamma (red colour). The compliance of the measurements is very high (Fig. 9). For the evaluation of the medium deceleration value from the record created by the mobile phone software named Diag was created. It loads and graphically shows the recorded process and also filters the data and calculates the medium value during the full braking.

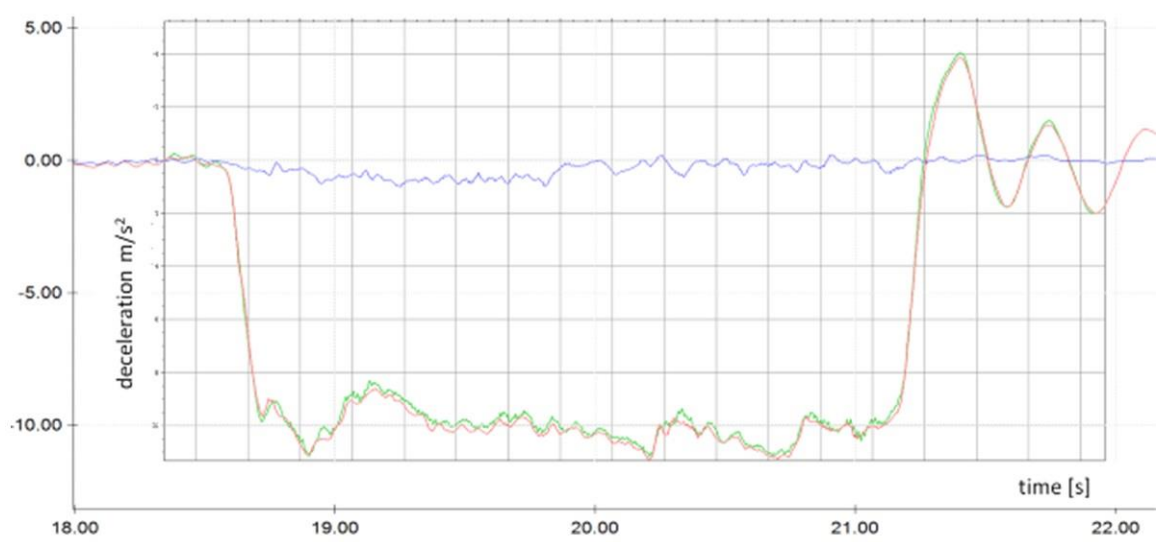

Fig. 9 Deceleration development comparison. Source: authors 
The methodology of the evaluation of the mean braking deceleration value by the mobile phone record was identical with the decelerometer XL Meter ${ }^{\mathrm{TM}}$ Pro Gamma measurements.

\section{Conclusion}

The authors of the article presented the compilation of executed and evaluated measurements of the mean braking deceleration value during the intensive braking. Measurements were performed on current modern vehicles on the dry asphalt surface. The authors introduced the possibilities of deceleration measurements carried out in a different ways and using different devices.

Interesting results represent the deceleration values on the dry surface, surprisingly high average values between 9.34 and $10.43 \mathrm{~m} / \mathrm{s}^{2}$. Finally, the obtained results and data can be further processed in forensic engineering.

\section{Acknowledgments}

This contribution is the result of the project implementation: 2/KCMD/2018 Centre of excellence for systems and services of intelligent transport II, ITMS 26220120050 supported by the Research \& Development Operational Programme funded by the ERDF.

\section{References}

[1] Burg, H. \& Moser, A. (2009). Handbuch Verkehrsunfall-rekonstruktion, Vieweg+Taubner, Wiesbaden, Germany.

[2] Hockicko, P. \& Trpišová, B. (2013). Are students' conceptions about automobile braking distances correct? In Engineering Education Fast Forward 1973 - 2013: proceedings of the 41st SEFI annual conference, 16-20 September. Leuven, Belgium. Brussels: SEFI.

[3] Šarkan, B. (2013). Diagnostics of road vehicles: instructions for exercises. Zilina: University of Zilina, EDIS, Slovak Republic.

[4] Vrábel, J., Jagelčák, J., Rievaj, V. \& Caban, J. (2014). The quality of the brake components and its impact on the basic parameters of braking. Machines, technologies, materials: international virtual journal, 8(6), 6-8.

[5] SW PC Crash, 10.9. (2018). Data processed by authors.

[6] Musicant, O., Botzer, A., Laufer, I. \& Collet, C. (2018). Relationship between Kinematic and Physiological Indices during Braking Events of Different Intensities. Human Factors, 60(3), 415-427. DOI: 10.1177/0018720817752595. 
[7] Lonkwic, P., Lygas, K., Wolszczak, P., Molski, S. \& Litak, G. (2017). Braking deceleration variability of progressive safety gears using statistical and wavelet analyses. Measurement, 110, 90-97. DOI: 10.1016/j.measurement.2017.06.005.

[8] Nadolski, R., Ludwinek, K., Staszak, J. \& Jaśkiewicz, M. (2012). Utilization of BLDC motor in electrical vehicles. Przeglad Elektrotechniczny, 88(4A), 180-186.

[9] Tak, S., Kim, S. \& Yeo, H. (2015). Development of a Deceleration-Based Surrogate Safety Measure for Rear-End Collision Risk. IEEE Transactions on Intelligent Transportation Systems, 16(5), 2435-2445. DOI: 10.1109/TITS.2015.2409374.

[10] Terzo, A., Gobbato, P., Masi, M. \& Rossi, A. (2016). An Engine/Vehicle Model to Assess the Theoretical Increase of Car Safety by Using the Spark Ignition Engine to Support the Conventional Braking System. International Journal of Braking Thermodynamics, 19(4), $187-$ 196. DOI: $10.5541 /$ ijot.5000156180.

[11] Sokolov, V. \& Krol, O. (2017). Installations Criterion of Deceleration Device in Volumetric Hydraulic Drive. In International Conference on Industrial Engineering (ICIE2017), Book Series: Procedia Engineering, 206, 16-19 May (pp. 936-943). Saint Petersburg, Russia. DOI: 10.1016/j.proeng.2017.10.575.

[12] Li, X., Yan, X., Wu, J., Radwan, E. \& Zhang, Y. (2016). A rear-end collision risk assessment model based on drivers' collision avoidance process under influences of cell phone use and gender-A driving simulator based study. Accident Analysis and Prevention, 97(1), 1-18. DOI: 10.1016/j.aap.2016.08.021.

[13] Haque, M.M. \& Washington, S. (2015). The impact of mobile phone distraction on the braking behaviour of young drivers: A hazard-based duration model. Transportation Research Part C: Emerging Technologies, 50, 13-27. DOI: 10.1016/j.trc.2014.07.011. 